\title{
Response of erythrocyte pyrimidine 5'-nucleotidase (P5N) activity in workers exposed to lead
}

\author{
M ICHIBA, K TOMOKUNI
}

From the Department of Community Health Science, Saga Medical School, Nabeshima, Saga 840-01, Japan

Erythrocyte pyrimidine 5 -nucleotidase (P5N) is an enzyme that catalyses the hydrolytic dephosphorylation of pyrimidine $5^{\prime}$-ribose monophosphate:uridine and cytidine 5 '-monophosphates (UMP and CMP). Its presence in the soluble fraction of human erythrocytes was first reported by Valentine et al in 1974, indicating that a severe deficiency of erythrocyte P5N is associated with hereditary haemolytic anaemia characterised by a pronounced increase in erythrocyte basophilic stippling.'

Recently, several investigators have reported that erythrocyte P5N activity is appreciably inhibited by lead, and the $\log$ of its activity has a good negative correlation with blood lead in lead workers $(r=-0.79$ to -0.80$) .^{23}$

To confirm these findings we have performed the erythrocyte $\mathrm{P} 5 \mathrm{~N}$ test in lead workers and compared the data obtained with other biological indices of lead exposure: blood lead $(\mathrm{PhB})$, erythrocyte $\delta$-aminolaevulinic acid dehydratase (ALAD), erythrocyte protoporphyrin (PROTO), urinary $\delta$-aminolaevulinic acid (ALA), and urinary coproporphyrin (COPRO).

Heparinised venous blood and spot urine were

Accepted 7 September 1987 obtained from 77 lead workers who were employed in factories producing lead pipe and lead plate and in a polyvinyl chloride factory. Erythrocyte P5N activity was measured by high performance liquid chromatography (HPLC). ${ }^{4}$ The concentration of $\mathrm{PbB}$ was determined by flameless atomic absorption spectrophotometry, erythrocyte ALAD activity by the method of Nikkanen et al, ${ }^{5}$ erythrocyte PROTO by the method of Piomelli, ${ }^{6}$ urinary ALA by the method of Tomokuni and Ogata, ${ }^{7}$ and urinary COPRO by a fluorometric method using HPLC. ${ }^{8}$

The concentration of $\mathrm{PbB}$ obtained from the lead workers ranged from 16 to $96 \mu \mathrm{g} / 100 \mathrm{ml}$. The workers were divided into two groups according to their blood lead concentrations: one group with $\mathrm{PbB}$ concentrations less than $40 \mu \mathrm{g} / 100 \mathrm{ml}$ and the other with $\mathrm{PbB}$ concentrations greater than $40 \mu \mathrm{g} / 100 \mathrm{ml}$. The arithmetric mean and SD in each group was $28 \pm 6 \mu \mathrm{g} / 100$ $\mathrm{ml}(\mathrm{n}=40)$ and $58 \pm 16 \mu \mathrm{g} / 100 \mathrm{ml}(\mathrm{n}=37)$, respectively. In each group correlation coefficients between erythrocyte $\mathrm{P} 5 \mathrm{~N}$ and other biological indices were calculated.

As shown in table 1, a negative correlation was found between $\mathrm{PbB}$ and P5N activity and between $\mathrm{PbB}$ and ALAD activity in 40 lead workers with $\mathrm{PbB}$ $<40 \mu \mathrm{g} / 100 \mathrm{ml}$. In this group the correlation

Table 1 Correlation matrix of biological indicators obtained from 40 lead workers with PbB $<40 \mu \mathrm{g} / 100 \mathrm{ml}$

\begin{tabular}{|c|c|c|c|c|c|}
\hline & P5N & $A L A D$ & PROTO & $A L A$ & COPRO \\
\hline $\begin{array}{l}\text { PbB } \\
\text { P5N } \\
\text { ALAD } \\
\text { PROTO } \\
\text { ALA }\end{array}$ & $-0.43^{* *}$ & $\begin{array}{c}-0.49 * * \\
0.30\end{array}$ & $\begin{array}{c}0.21 \\
-0.50^{* *} \\
-0.37^{*}\end{array}$ & $\begin{array}{r}0.17 \\
-0.06 \\
-0.17 \\
0.19\end{array}$ & $\begin{array}{r}0.26 \\
-0.07 \\
-0.10 \\
-0.00 \\
0.17\end{array}$ \\
\hline
\end{tabular}

${ }^{*} \mathrm{p}<0.05 ;{ }^{* *} \mathrm{p}<0.01$.

Table 2 Correlation matrix of biological indicators obtained from 37 lead workers with $\mathrm{PbB} \geqslant 40 \mu \mathrm{g} / 100 \mathrm{ml}$

\begin{tabular}{|c|c|c|c|c|c|}
\hline & $P 5 N$ & $A L A D$ & PROTO & $A L A$ & COPRO \\
\hline $\begin{array}{l}\text { PbB } \\
\text { PSN } \\
\text { ALAD } \\
\text { PROTO } \\
\text { ALA }\end{array}$ & $-0.78^{* * *}$ & $\begin{array}{r}-0.51 * * * \\
0.59 * * *\end{array}$ & $\begin{array}{r}0.75^{* * *} \\
-0.74^{* * *} \\
-0.52^{* *}\end{array}$ & $\begin{array}{c}0.70^{* * *} \\
-0.49^{* *} \\
-0.33^{*} \\
0.62^{* * *}\end{array}$ & $\begin{array}{l}0.55^{* * *} \\
-0.56^{* * *} \\
-0.34^{*} \\
0.68^{* * *} \\
0.80^{* * *}\end{array}$ \\
\hline
\end{tabular}


Table 3 Correlation matrix of biological indices obtained from 77 lead workers

\begin{tabular}{|c|c|c|c|c|c|}
\hline & P5N & $A L A D$ & PROTO & $A L A$ & COPRO \\
\hline $\begin{array}{l}\text { PbB } \\
\text { P5N } \\
\text { ALAD } \\
\text { PROTO } \\
\text { ALA }\end{array}$ & $-0.82^{* *}$ & $\begin{array}{r}-0.60^{* *} \\
0.59^{* *}\end{array}$ & $\begin{array}{r}0.72^{* *} \\
-0.75^{* *} \\
-0.55^{* *}\end{array}$ & $\begin{array}{c}0.66^{* *} \\
-0.52^{* *} \\
-0.35^{*} \\
0.63^{* *}\end{array}$ & $\begin{array}{r}0.61^{* *} \\
-0.58^{* *} \\
-0.37^{*} \\
0.68^{* *} \\
0.82^{* *}\end{array}$ \\
\hline
\end{tabular}

${ }^{*} p<0.01 ;{ }^{* *} p<0.001$.

coefficient for $\mathrm{PbB} v \mathrm{ALAD}$ was greater than that for $\mathrm{PbB} v \mathrm{P} 5 \mathrm{~N}$.

Table 2 shows the correlation matrix of the biological indicators obtained from 37 lead workers with $\mathrm{PbB} \geqslant 40 \mu \mathrm{g} / 100 \mathrm{ml}$. The concentration of $\mathrm{PbB}$ correlated significantly with all the indices examined. The intensity of correlation between $\mathrm{PbB}$ and other biological parameters increased in the order: ALAD$<$ COPRO $<$ ALA $<$ PROTO $<$ P5N. Although erythrocyte $\mathrm{P} 5 \mathrm{~N}$ activity correlated significantly with all the indicators tested, it had an especially high negative correlation with $\mathrm{PbB}$ and erythrocyte PROTO. From the results shown in tables 1 and 2, it is estimated that the erythrocyte P5N test is useful in monitoring exposure to lead at a comparatively high level.

The correlation coefficients for all the 77 lead workers are summarised in table 3 . The correlation coefficient between erythrocyte $\mathrm{P} 5 \mathrm{~N}$ and other biological indicators increased in the order: ALA <COPRO $<$ ALAD $<$ PROTO $<$ PbB. These data support the results described by Mohammed-Brahim et $a l^{2}$ and Sakai and Ushio. ${ }^{3}$

In conclusion, the erythrocyte P5N test is a useful biological monitor for exposure to lead in a wide range, indicating that its activity is useful in predicting the disturbance in porphyrin metabolism induced by lead.

We thank Dr K Sugimoto and his coworkers, Osaka
Prefectural Institute of Public Health, for their help in collecting samples from lead workers.

\section{References}

1 Valentine WN, Fink K, Paglia DE, Harris SR, Adams WS. Hereditary hemolytic anemia with human erythrocyte pyrimidine 5 '-nucleotidase deficiency. $J$ Clin Invest 1974;54:866-79.

2 Mohammed-Brahim B, Buchet JP, Lauwerys R. Erythrocyte pyrimidine 5'-nucleotidase activity in workers exposed to lead, mercury or cadmium. Int Arch Occup Environ Health 1985;55:247-52.

3 Sakai T, Ushio K. A simplified method for determining erythrocyte pyrimidine $5^{\prime}$-nucleotidase (P5N) activity by HPLC and its value in monitoring lead exposure. $\mathrm{Br} \mathrm{J}$ Ind Med 1986; 43:839-44.

4 Tomokuni K, Ichiba M. Simple determination of erythrocyte pyrimidine 5 -nucleotidase activity in human blood by high performance liquid chromatography. Ind Health 1986;24:22733.

5 Nikkanen J, Hernberg S, Tola S. Modifications of the deltaaminolevulinic acid dehydratase test and their significance for assessing different intensities of lead exposure. Work Environ Health 1972;9:46-52.

6 Piomelli S. A micromethod for erythrocyte porphyrins; the FEP test. J Lab Clin Med 1973;81:932-40.

7 Tomokuni K, Ogata M. Simple method for determination of urinary $\delta$-aminolevulinic acid as an index of lead exposure. Clin Chem 1972;18:1534-6.

8 Tomokuni K, Hirai Y. Simple liquid-chromatographic determination of urinary coproporphyrin in workers exposed to lead. Clin Chem 1986;32:872-3. 